\title{
A!
}

This is an electronic reprint of the original article.

This reprint may differ from the original in pagination and typographic detail.

Jämsä-Jounela, Sirkka-Liisa; Dietrich, Maija; Halmevaara, Kalle; Tiili, Otso

\section{Control of pulp levels flotation cells}

Published in:

Control Engineering Practice

Published: 01/01/2003

Document Version

Peer reviewed version

Please cite the original version:

Jämsä-Jounela, S-L., Dietrich, M., Halmevaara, K., \& Tiili, O. (2003). Control of pulp levels flotation cells. Control Engineering Practice, 11(1), 73-81.

This material is protected by copyright and other intellectual property rights, and duplication or sale of all or part of any of the repository collections is not permitted, except that material may be duplicated by you for your research use or educational purposes in electronic or print form. You must obtain permission for any other use. Electronic or print copies may not be offered, whether for sale or otherwise to anyone who is not an authorised user. 


\title{
Control of pulp levels in flotation cells
}

\author{
S.-L. Jämsä-Jounela*, M. Dietrich, K. Halmevaara, O. Tiili \\ Laboratory of Process Control and Automation, Aalto University, P.O. Box 6100, Kemistintie 1, 02150 Espoo, Finland
}

\begin{abstract}
The control of pulp levels in flotation cells is a complex control task. Many different aspects such as cell structure and valve sizing, and their effects on control, have to be taken into account. Control becomes more and more difficult as the complexity of the cell configurations and the number of cells used in configuration increase. In this paper the mathematical model of a flotation cell is first developed and several configurations of cells are constructed. Simulations are then performed in order to determine suitable control parameters for PI and feed-forward controllers of the cell levels. Finally, the effects of valve sizing and cell structure are presented and discussed.
\end{abstract}

(C) 2003 Elsevier Science Ltd. All rights reserved.

Keywords:

Level control; Control valves; Characteristic curves; Valve sizing; Flotation

\section{Introduction}

A flotation plant control system usually consists of conventional single-loop controllers. Due to the physical characteristics of the flotation process, especially the disturbances caused by varying composition of the raw ore, their efficiency has been found to be limited. Some new advanced control methods have been recommended for the control of flotation processes (Stenlund \& Medvedev, 2000). Niemi, Maijanen, and Nihtilä (1974), Koivo and Cojocariu (1977) used a single cell model when developing an optimal control algorithm via applications of the maximum principle. Andersen et al. (1979) and Zargiza and Herbst (1987) reported an application of state feedback control and a Kalman filter for rougher flotation control. Hammoude and Smith (1981) used a linear model to develop a minimumvariance controller for re-cleaning. However, the use and maintenance of control systems based on modern control theory have proved to be problematic in the industrial environment. As a result, expert control strategies for the logic control of situations not governed by continuous control have been introduced (Jämsä \& Herbst, 1988).

(C) 2003 Elsevier Science Ltd. All rights reserved.
On an industrial scale, flotation is usually performed in large cells connected in series. In addition to the tank itself, each flotation cell also contains a mechanism for injecting air into the bottom of the cell through the rotors; the launders are located at the top of the cell, as well as occasionally structures to funnel the froth towards the launders.

In the control of flotation circuits the froth height can be used to control either the concentrate or the tailings grade from a specific flotation bank. Increasing the froth height increases the particle residence time in the froth phase, thus increasing gangue drainage. This produces a higher concentrate grade, although often at the expense of a slight loss of recovery. Advanced control strategies often use cell levels as manipulated variables. Therefore properly tuned and well performing level controls are a basis for successful flotation control.

A set of conventional single-loop controllers is commonly used, although many problems have been reported, e.g. cyclic or interactive disturbances that frequently occur in plants with connected stages and recycled streams (Schubert, Henning, Hulbert, \& Craig, 1995). The major disturbances in the operation of a flotation circuit are caused by changes in the properties of the ore, or by instabilities in the grinding. Large variations in the flow rate of the flotation feed caused by fluctuations in the performance of the grinding circuit are not uncommon in concentrators. Disturbances of 
this kind are undesirable because they are transmitted through the flotation circuit, causing instabilities in its performance.

The aim of this research is to study flotation control mainly from the point of view of cell level control by developing a simulation platform for controller design. The first part of the research consisted of a detailed study of the effects of cell configuration and valve sizing on the control of flotation cells in series. The final aim of the project is the development of software for the plant operators, which provides advice in the selection of tuning parameters for the cell level controls.

In the following the mathematical model of a flotation cell is first developed and several cell configurations are constructed. The simulations are then performed in order to determine suitable control parameters for PI and feed-forward controllers of the cell levels. Furthermore, a study is carried out on the effect of valve sizing on control by sizing the valves with equations obtained from the literature. The developed platform is utilised in further research on control strategies (Kämpjärvi \& Jämsä-Jounela, 2002). Simulation was performed with Matlab 5.2.0 and its Simulink library.

\section{Mathematical modelling of flotation cells in series}

In the flotation process the pulp is fed into the first cell and the froth is collected in the launders. The feed can be measured, e.g. by a magnetic flow meter, and the remaining pulp flows into the next cell. The magnitude of the flow depends on the pressure difference between two adjacent cells, the position of control valves, and the viscosity and density of the pulp. The pressure difference can be determined from the physical height difference of the cells. The pulp level in a cell is measured and controlled by adjusting the control valve.

In the following, a flotation cell is considered as a tank of perfectly mixed pulp. Since the pulp is perfectly mixed, the density is constant throughout the cell, i.e. there are no spatial density gradients in the cell. As the froth flow is small compared to the pulp flow, it is ignored in the outgoing flows. The impact of the air feed on the pulp level is also ignored.
The cells under study do not have the properties of ideal tanks because the cross-sectional area of the cell is not constant. A mathematical model for the physical properties will be developed and discussed next.

\subsection{Single cells in series}

In flotation several single cells are connected in series as shown in Fig. 1.

The change in volume of the pulp with respect to time can be denoted for each cell in series using continuity equations.

For the first cell in the series:

$\frac{\partial V_{1}}{\partial t}=\left(q-F_{1}\right)=q-K C_{v}\left(u_{1}\right) \sqrt{y_{1}-y_{2}+h_{1}}$,

where $q$ is the feed rate to the first cell, $y_{1}$ the pulp level in the first cell, $y_{2}$ the pulp level in the second cell, $h_{1}$ the physical difference in height between the cells, $u_{1}$ the control signal, $K$ the constant coefficient, $F_{1}$ the outflow from the first cell and $C_{v}$ the valve coefficient.

The equations for cells 2,3 and 4 are, respectively $(i=2,3$ and 4$)$

$$
\begin{aligned}
\frac{\partial V_{i}}{\partial t}= & \left(F_{i-1}-F_{i}\right) \\
= & K C_{v}\left(u_{i-1}\right) \sqrt{y_{i-1}-y_{i}+h_{i-1}} \\
& -K C_{v}\left(u_{i}\right) \sqrt{y_{i}-y_{i+1}+h_{i}} .
\end{aligned}
$$

The equation for the last cell $(n=5)$ is

$$
\begin{aligned}
\frac{\partial V_{n}}{\partial t}= & \left(F_{n-1}-F_{n}\right) \\
= & K C_{v}\left(u_{n-1}\right) \sqrt{y_{n-1}-y_{n}+h_{n-1}} \\
& -K C_{v}\left(u_{n}\right) \sqrt{y_{n}+h_{n}} .
\end{aligned}
$$

In the case of an ideal tank, the cross-section of a cell is assumed to be constant. The pulp levels in the cells can therefore be written as

$$
\begin{aligned}
\frac{\partial y_{1}}{\partial t} & =\frac{\left(q-F_{1}\right)}{A_{1}} \\
& =\frac{q-K C_{v}\left(u_{1}\right) \sqrt{y_{1}-y_{2}+h_{1}}}{A_{1}},
\end{aligned}
$$

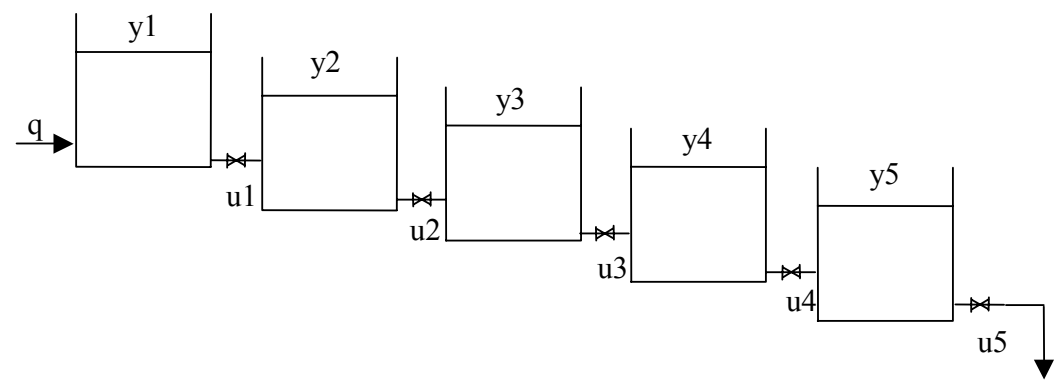

Fig. 1. Schematic diagram of a flotation series. 


$$
\begin{aligned}
\frac{\partial y_{i}}{\partial t}= & \frac{K_{i-1} C_{v}\left(u_{i-1}\right) \sqrt{y_{i-1}-y_{i}+h_{i-1}}}{A_{i}} \\
& -\frac{K C_{v}\left(u_{i}\right) \sqrt{y_{i}-y_{i+1}+h_{i}}}{A_{i}},
\end{aligned}
$$

where $i=2,3,4$.

$$
\begin{aligned}
\frac{\partial y_{n}}{\partial t}= & \frac{K C_{v}\left(u_{n-1}\right) \sqrt{y_{n-1}-y_{n}+h_{n-1}}}{A_{n}} \\
& -\frac{K C_{v}\left(u_{n}\right) \sqrt{y_{n}+h_{n}}}{A_{n}},
\end{aligned}
$$

where $n=5$.

\subsection{Double cells in series}

Mathematical models for the double cells can be derived in a similar manner. In a double cell, both pulp levels are controlled by manipulating a control valve in the second cell outflow, as can be seen from Fig. 2. The cells are physically on the same level.

The pulp level in the second cell is measured and compared with the set point. This signal is used as input to a digital PI controller. The output signal of the controller is the desired valve position as denoted by $u_{1}$. The cells in a double cell are connected via a flange. The flange limits the maximum flow between the cells. The pressure difference in the cells is the only driving force for the flow, and depends on the density of the pulp.

The velocity of outflow from the first cell can be derived using Bernoulli's equation, resulting in

$v=\sqrt{2 g\left(y_{1}-y_{2}\right)}$,

where $g$ is the gravity, $y_{1}$ the pulp level in the first cell, $y_{2}$ the pulp level in the second cell.

The volume flow across the flange can be calculated as

$F_{1}=v A_{\text {flange }}=\sqrt{2 g\left(y_{1}-y_{2}\right)} l_{l} h_{l}$,

where $A_{\text {flange }}$ is the cross-sectional area of the flange, $l_{l}$ the length of the flange, and $h_{l}$ the height of the flange.

The pressure drop due to flowing resistances is assumed to be negligible and can be ignored. The change of the pulp volume in the first cell with respect to time can be written as

$\frac{\partial V_{1}}{\partial t}=q-F=q-\sqrt{2 g\left(y_{1}-y_{2}\right)} l_{l} h_{l}$.

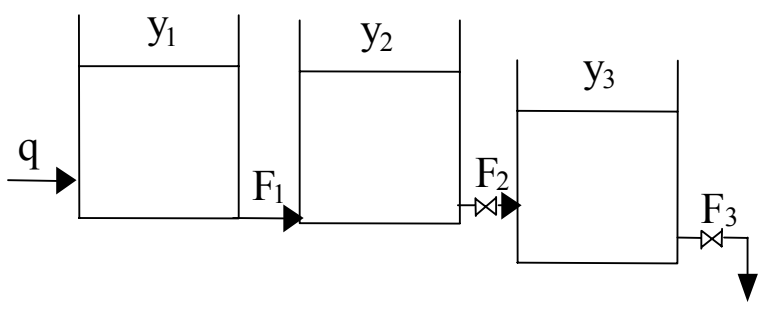

Fig. 2. Double flotation cell series.
The outflow of the second double cell is similar to that of a single cell, and the flow into the second cell is the outflow of the first. Therefore the mathematical model is

$$
\begin{aligned}
\frac{\partial V_{2}}{\partial t}= & F_{1}-F \\
= & \sqrt{2 g\left(y_{1}-y_{2}\right)} l_{l} h_{l} \\
& -K_{2} C_{v}\left(u_{1}\right) \sqrt{y_{2}-y_{3}+h_{1}} .
\end{aligned}
$$

\subsection{Modelling the non-linear flotation cells}

Due to the froth collecting structures inside the modelled non-linear flotation cells (Fig. 3) the relation between the pulp volume and level is not linear.

The effect of pulp level non-linearity can be seen in Fig. 4, in which the pulp level is presented in ideal tank conditions as a function of the pulp volume. The cell type is TC-50, the maximum volume of which is $50 \mathrm{~m}^{3}$.

\subsection{Valve sizing and characteristic curve of the valves}

Valve sizing is based on the $C_{v}$ value, which is calculated according to the ISA standard as follows:

$C_{v}=1.17 Q \sqrt{\frac{\rho}{\Delta p}}$,

where $Q$ is the flow rate $\left(\mathrm{m}^{3} / \mathrm{h}\right), C_{v}$ the valve capacity coefficient, $\rho$ the pulp density $\left(\mathrm{kg} / \mathrm{m}^{3}\right)$, and $\Delta p$ the pressure difference over the valve.

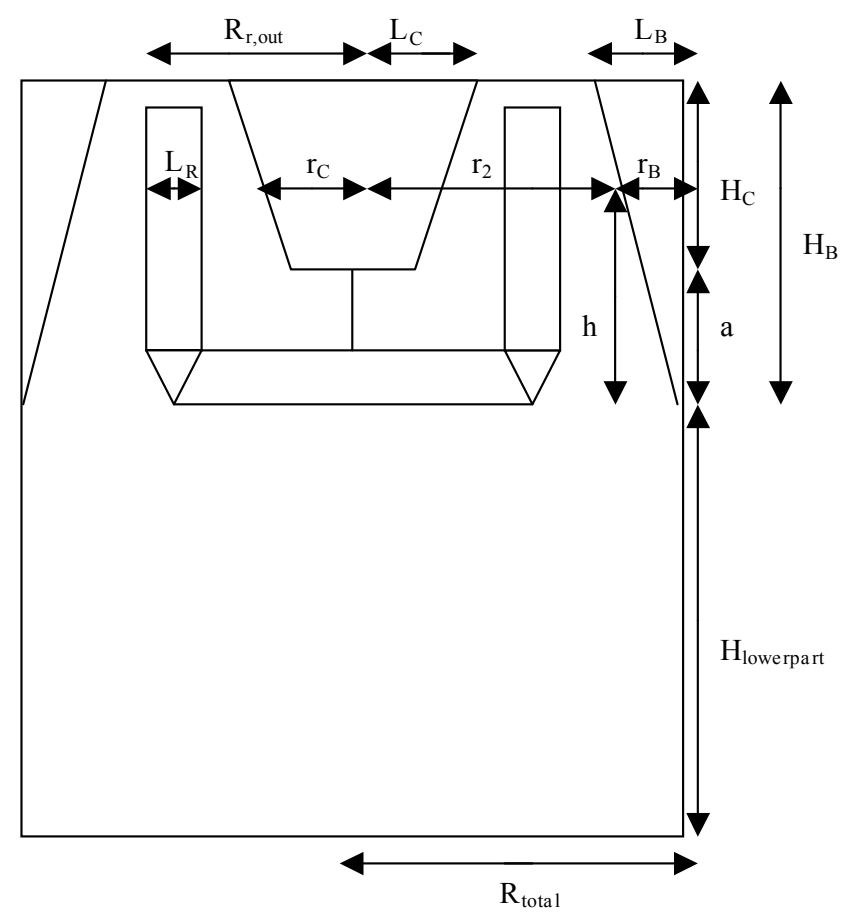

Fig. 3. Cross-section of a non-linear flotation cell. 


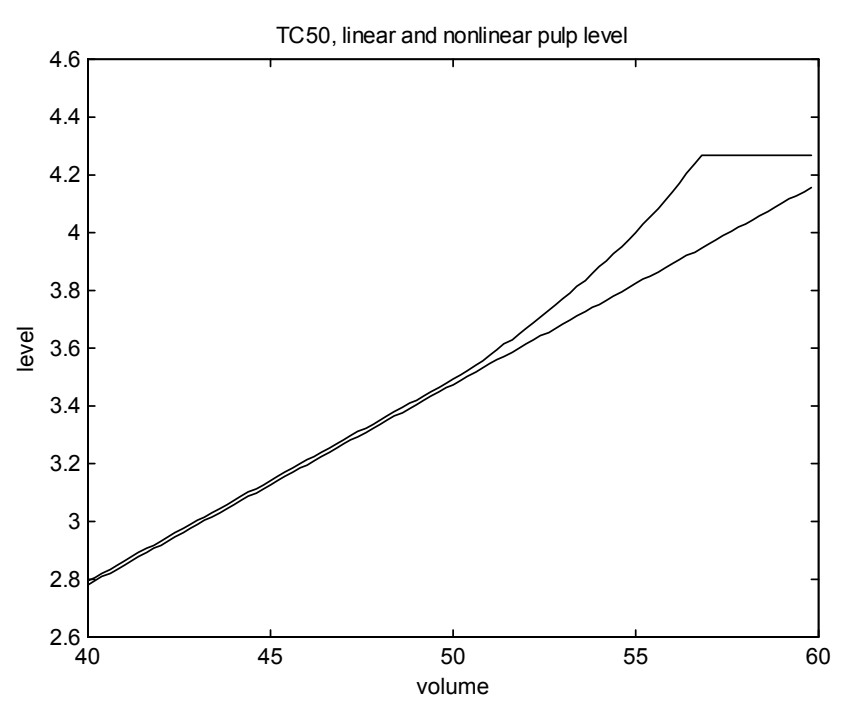

Fig. 4. Pulp level as a function of pulp volume.

The mean flow rate $\left(\mathrm{m}^{3} / \mathrm{h}\right)$ through the cell is calculated as

$Q=1.2 \frac{V_{\text {cell }}}{\tau / 60}$,

where $V_{\text {cell }}$ is the cell volume $\left(\mathrm{m}^{3}\right)$ and $\tau$ is the pulp retention time in the cell.

The valves in the models are sized for a flow having a retention time of $1.5 \mathrm{~min}$ in one cell. Characteristic curves of the control valves are produced by Larox Flowsys and were used in the Simulink models in order to cause realistic and non-linear behaviour for the valves.

\section{Cell level control}

In industrial applications each flotation cell has separate PI controller for the level control via the control valve of the cell outflow. In the simulation study the following PI algorithm is used:

$\Delta u_{i}=K\left(\left(e_{i}-e_{i-1}\right)+\frac{T}{I} e_{i}\right)$,

where $\Delta u$ is a calculated change in the control output, $K$ the proportional gain, $I$ the integration time, $e_{i}$ a current error term (set point - process variable), $e_{i-1}$ a previous error term ( $T$ seconds ago), and $T$ is the sampling interval (seconds).

In industrial process control applications (Niemi et al., 1974) feed-forward compensation of measurable disturbances is commonly and successfully used. Available feed flow measurement makes the feed-forward level control possible.

The main purpose of the feed-forward level control is to observe the disturbance in the inflow of the first cell

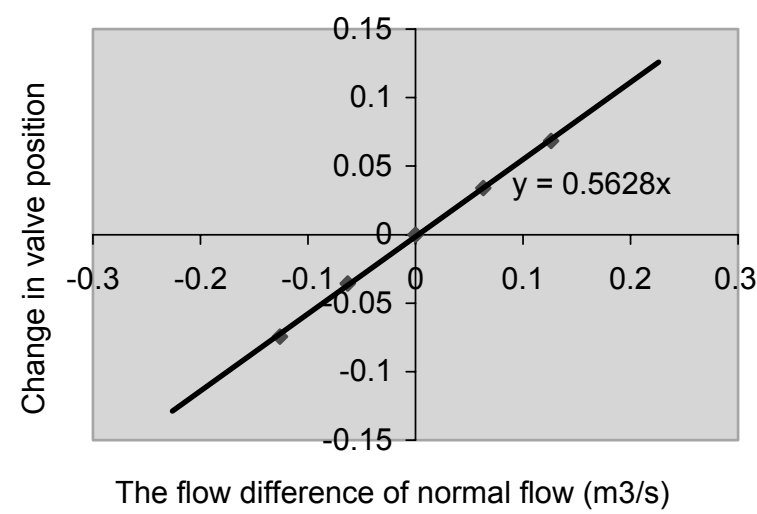

Fig. 5. Change in valve position as a function of the flow difference for a $525 \mathrm{~mm}$ valve.

by measuring the flow rate, and then to open or close the valves of the cell in order to compensate the disturbance as fast and efficiently as possible.

When using feed-forward control, compensation is linearly dependent on the difference between the current inflow and the normal inflow. An example of the change in valve position as a function of the difference in flow compared to the normal flow conditions is presented in Fig. 5. The correlation is determined by using the leastsquare method. The achieved change in the valve position is added to the valve position signal coming from the PI controller. The measurement signal is filtered in order to prevent the feed-forward control from reacting to random variation in the flow.

\section{Simulations}

\subsection{Cell configurations}

In the simulations the configurations of three and six TC-50 cells in series were studied (1) with the ideal tank assumption, and (2) with the non-linear cell model. The simulations were performed by using the valves sized according to the ISA standard and with $100 \%$ oversizing. Control strategies with conventional PI controllers and with feed-forward control were simulated. The simulated configurations are presented in Fig. 6.

\subsection{Performance criteria}

The performance criteria set for the comparison of alternative designs are overshoot, rise time (i.e. time for the response to reach the desired value for the first time) and settling time (time for the response to settle within $\pm 5 \%$ of the desired value). The closed loop responses are used for calculating the dynamic performance criterion of integral of the square error (ISE) and integral of the absolute value of 


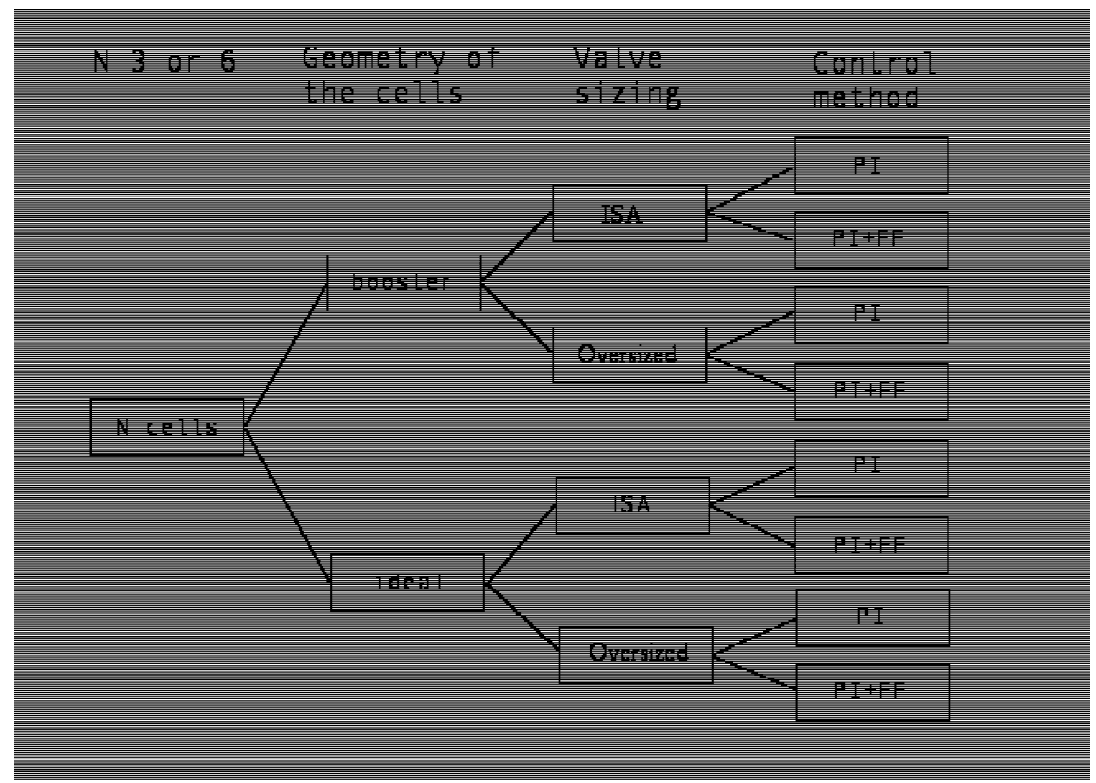

Fig. 6. The simulation configurations of conventional PI controllers and PI controllers with feed-forward control.

the error (IAE):

$I S E=\int_{t=t_{1}}^{t_{2}}\left(y(t)-y_{s p}(t)\right)^{2} \mathrm{~d} t$,

$I A E=\int_{t=t_{1}}^{t_{2}}\left|y(t)-y_{s p}(t)\right| \mathrm{d} t$.

\subsection{Simulation schemes}

The simulation schemes were constructed with Matlab 5.2.0 Simulink software. A simulation scheme of non-linear cell is presented in Fig. 7.

\section{Simulation results}

The simulation results for systems with the ideal tanks and non-linear cells show that the cell levels can be controlled more accurately using valves sized according to the ISA standard (Fig. 8 and Table 1). There were only minor differences in overshoots and in the settling times.

A somewhat larger improvement in cell level control was accomplished when feed-forward control was implemented. In the case of disturbances in the feed, the overshoots performed by the last cells are significantly smaller (Fig. 9 and Table 2).

The results in Fig. 10 and Table 3 also demonstrate that there can be differences in control performance between ideal tanks and non-linear cells. The disturbances in feed were easier to compensate in configurations based on the ideal tank assumption.

The set point changes could be performed fluently in the case of the ideal tank assumption, as can be seen from Fig. 11. There were considerable differences in oscillation and settling time between the ideal tanks and non-linear cells. The new set point was reached rapidly and with only small oscillation in the case of ideal tanks.

Feed-forward control applied to double cell configurations improved control performance in a similar manner as in the single cell configurations, as can be seen in Fig. 12 and Table 4.

\section{Pilot plant tests}

The influence of valve sizing and additional feedforward control were also studied in a pilot plant (Jämsä-Jounela, Laurila, Karesvuori, \& Timperi, 2001). The test configuration consisted of a flotation cell, pulp circulation cell, pulp pump, air feed device and two different control valves. The inflow was measured with a magnetic flow meter and the pulp level with a float. The tests were performed with a flotation cell with similar geometries as described above. The results achieved were analogous to those obtained in the simulations (Fig. 13). The control performance was noticeably improved by adding the feed-forward control. It was also found that an adaptive feed-forward control gain could result in even greater improvements in control performance. 


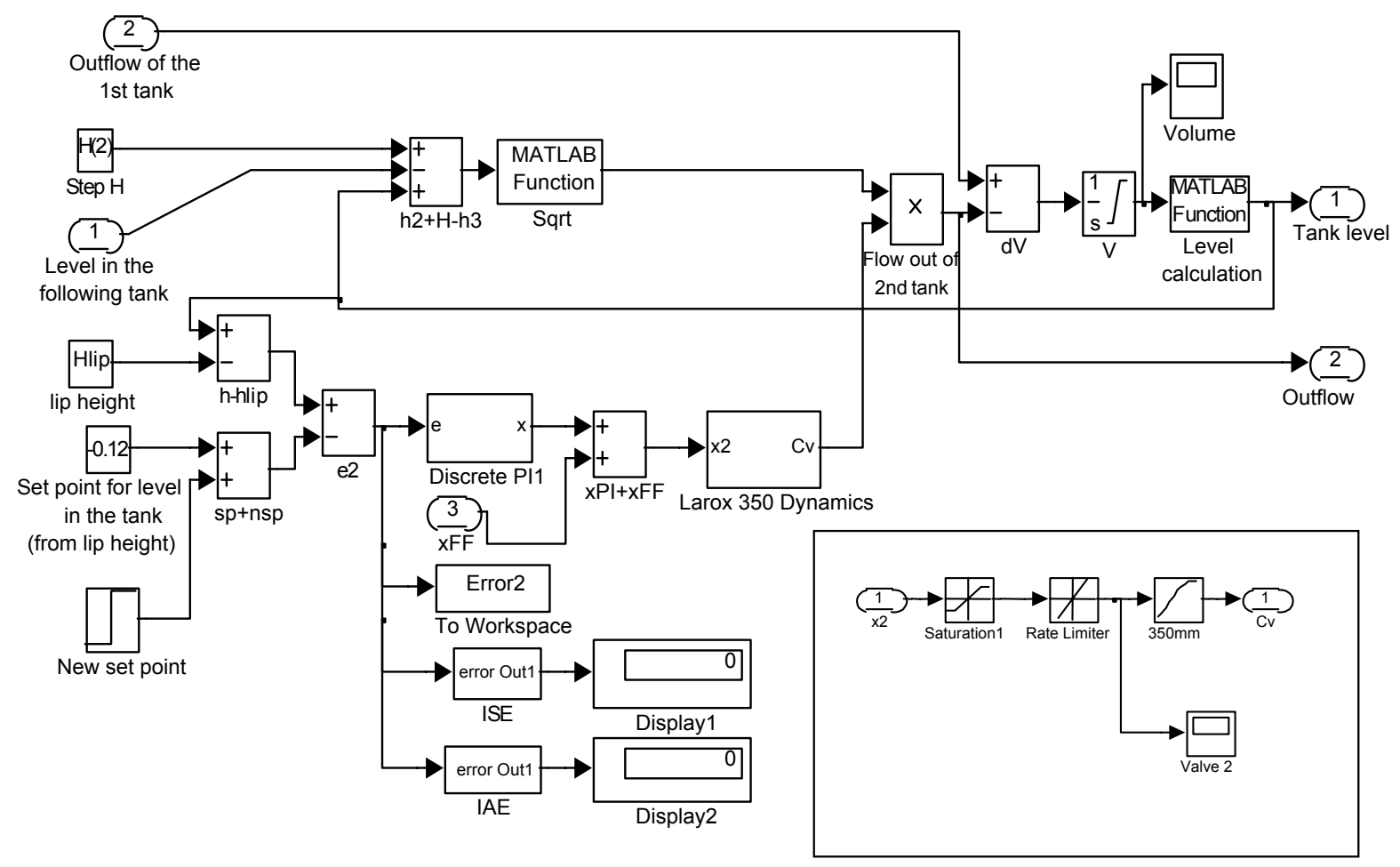

Fig. 7. Simulink model of the flow dynamics in a flotation cell.
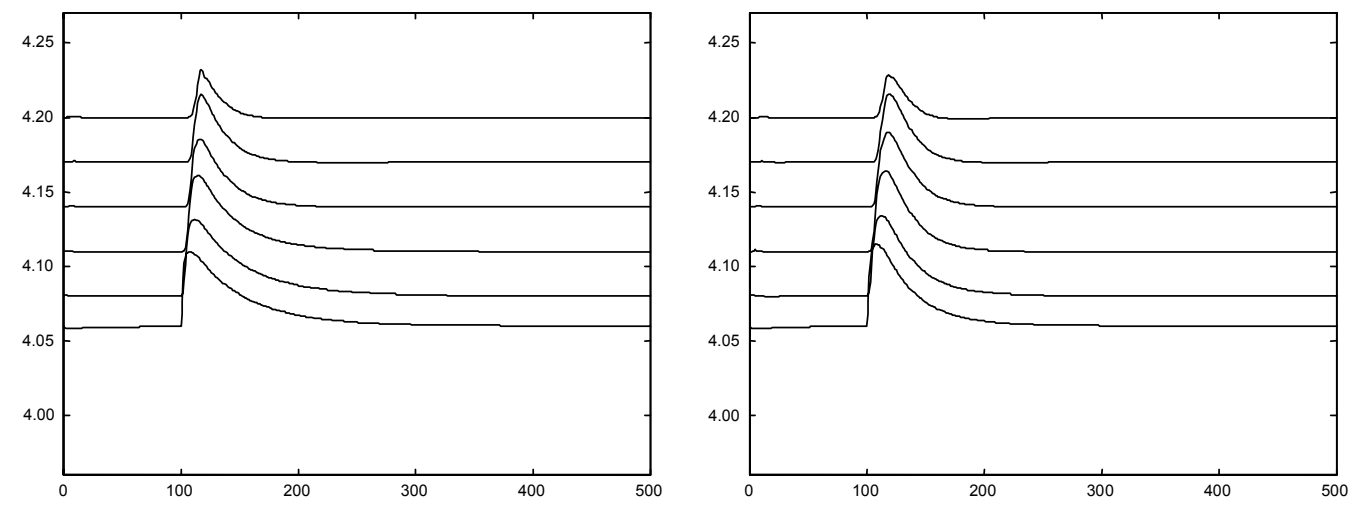

Fig. 8. Response of the levels to a $+20 \%$ change in pulp feed. On the left for $100 \%$ valve oversizing, and on the right for valve sizing according to the ISA standard.

Table 1

The influence of valve sizing: response of the pulp level in the last cell to a $+20 \%$ change in the feed

\begin{tabular}{|c|c|c|c|c|c|c|c|}
\hline Configuration & Overshoot (cm) & Overshoot (\%) & Rise time (s) & Settling time (s) & Dead time (s) & ISE & IAE \\
\hline TC50 111111525 & 3.2 & 0.762 & 2.5 & 55 & 7 & 0.01248 & 0.6838 \\
\hline TC50 111111350 & 2.8 & 0.667 & 2.8 & 49 & 8 & 0.01221 & 0.6815 \\
\hline
\end{tabular}



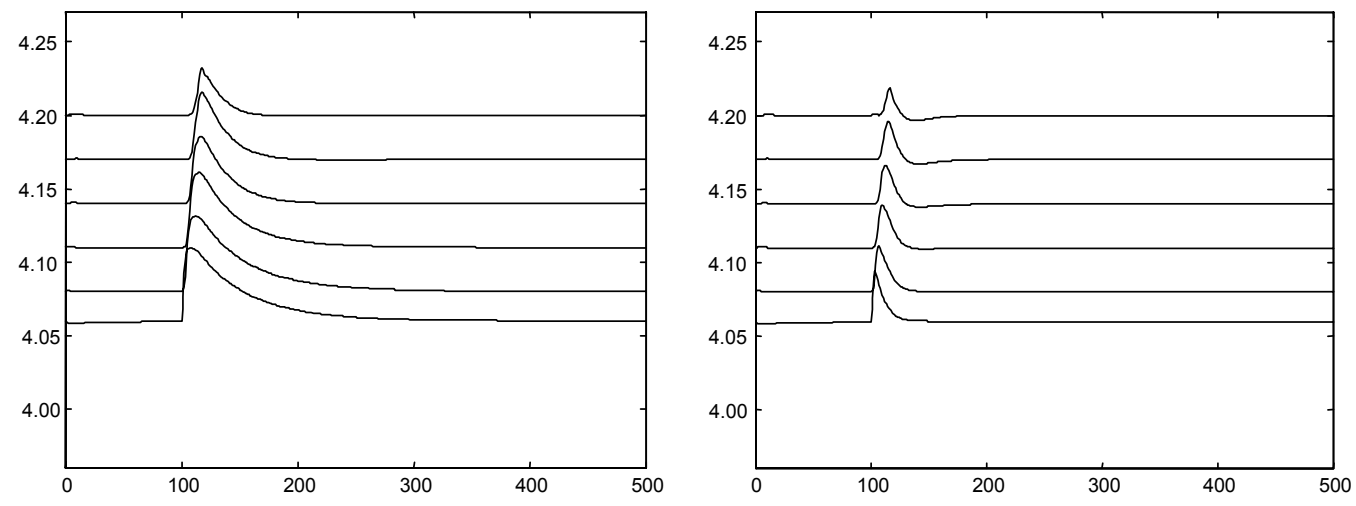

Fig. 9. Response of the levels to a $+20 \%$ change in pulp feed. $100 \%$ valve oversizing is used in both figures. On the left PI controller, and on the right PI controller and feedforward controller.

Table 2

The influence of feed-forward control: response of the pulp level in the last cell to a $+20 \%$ change in the feed

\begin{tabular}{llllllll}
\hline Configuration & Overshoot $(\mathrm{cm})$ & Overshoot $(\%)$ & Rise time (s) & Settling time (s) & Dead time (s) & ISE & IAE \\
\hline TC50 111111 525 & 3.2 & 0.762 & 2.5 & 55 & 7 & 0.01248 & 0.6838 \\
TC50 111111 525 FF & 1.84 & 0.438 & 2.4 & 55 & 0.5 & 0.00216 & 0.2686 \\
\hline
\end{tabular}
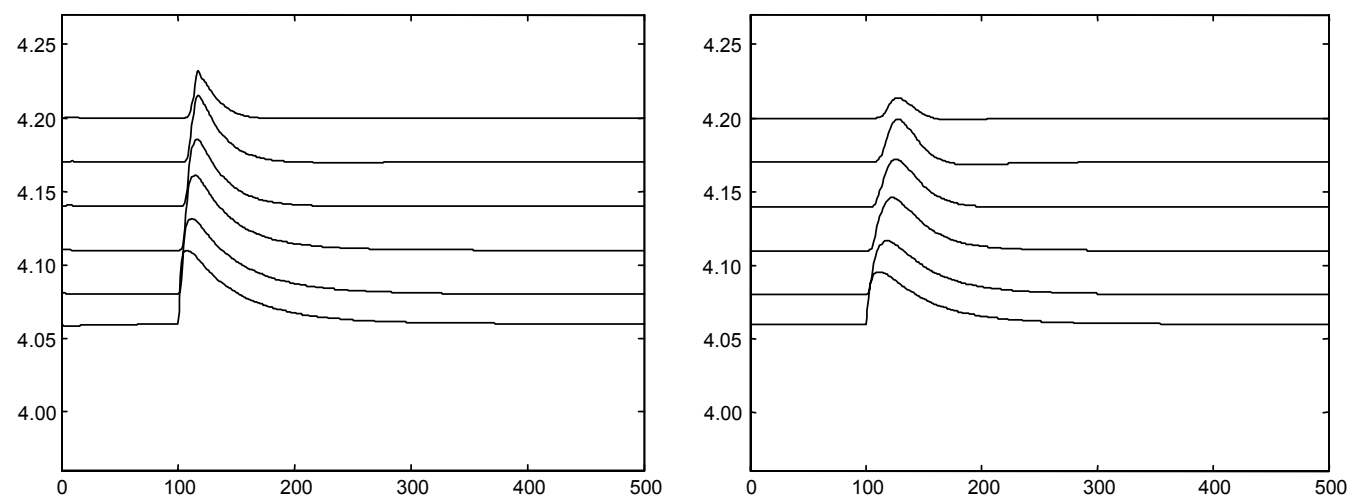

Fig. 10. Response of the levels to a $+20 \%$ change in pulp feed. $100 \%$ valve oversizing is used in both figures. On the left are non-linear cells, and on the right model based on the ideal tank assumption.

Table 3

The influence of cell geometry: response of the pulp level in the last cell to a $+20 \%$ change in the feed

\begin{tabular}{llllllll}
\hline Configuration & Overshoot $(\mathrm{cm})$ & Overshoot $(\%)$ & Rise time (s) & Settling time (s) & Dead time (s) & ISE & IAE \\
\hline TC50 111111 525 nonlinear & 3.2 & 0.762 & 2.5 & 55 & 7 & 0.01248 & 0.6838 \\
TC50 111111 525 linear & 1.35 & 0.321 & 3 & 42 & 10 & 0.003334 & 0.3956 \\
\hline
\end{tabular}

\section{Conclusions}

All the simulated configurations were successfully tuned. Different valve sizes and different cell types had an effect on the proportional gain of the PI control: the proportional gains were larger when using valves sized according to the ISA standard than with oversized valves. Similarly, the proportional gains were larger in the case of ideal tanks than with cells. Higher proportional gains reduce the settling time of the system in PI control. The opening speeds (from $0 \%$ to $100 \%$ ) of the valves have been estimated to be $30 \mathrm{~s}$ regardless of the valve size, i.e. the bigger the valve, the shorter the rise time.

The valves were sized according to the ISA standard, and the retention time in each cell was $1.5 \mathrm{~min}$. The 

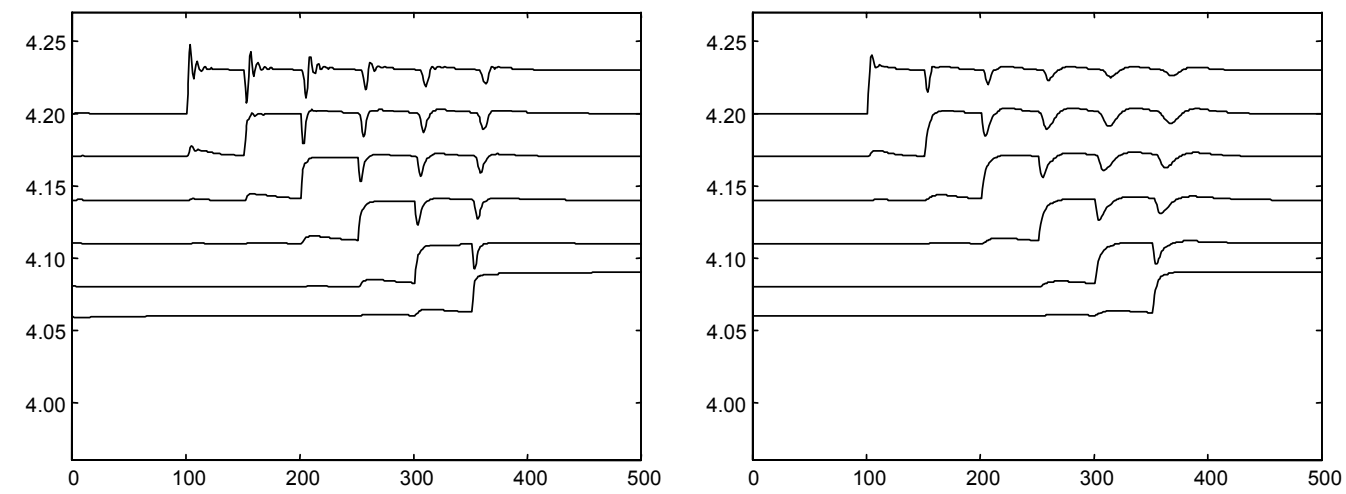

Fig. 11. Response of the levels to a $+3 \mathrm{~cm}$ change in the set points. $100 \%$ valve oversizing is used in both figures. On the left are non-linear cells, and on the right is the model based on the ideal tank assumption.
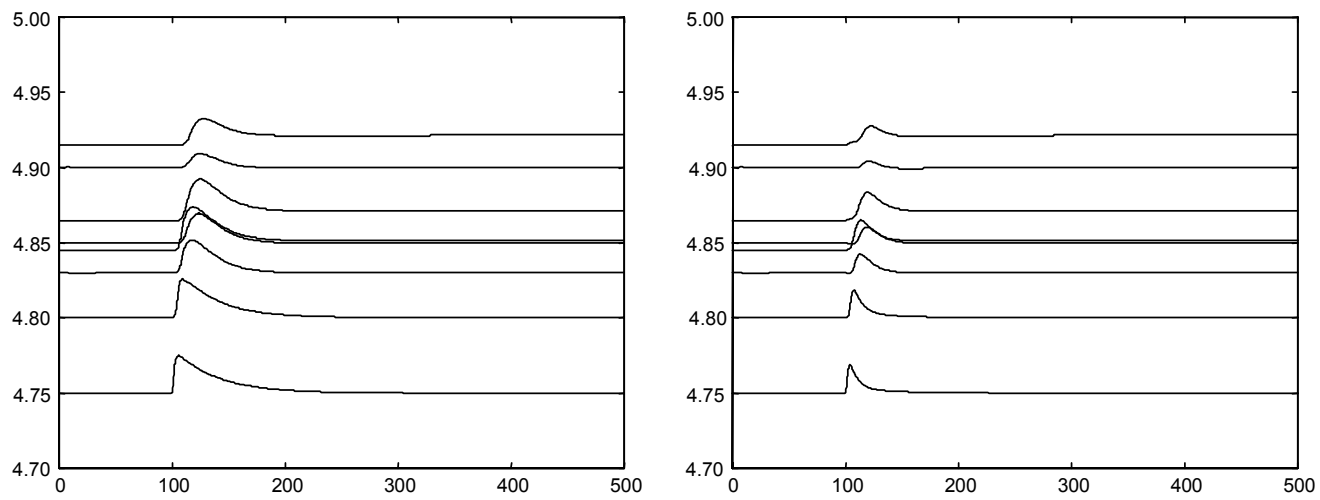

Fig. 12. Response of the levels to a $+20 \%$ change in pulp feed. $100 \%$ valve oversizing is used in both figures. On the left is the PI controller, and on the right, PI controller and feedforward controller.

Table 4

The influence of feed-forward control on the configuration with double cells: response of the pulp level in the last cell to a $+20 \%$ change in the feed

\begin{tabular}{|c|c|c|c|c|c|c|c|}
\hline Configuration & Overshoot $(\mathrm{cm})$ & Overshoot (\%) & Rise time (s) & Settling time (s) & Dead time (s) & ISE & IAE \\
\hline TC130 11222525 & 0.92 & 0.184 & 3 & 47 & 8 & 0.00175 & 0.2884 \\
\hline TC130 $11222525 \mathrm{FF}$ & 0.4 & 0.08 & 4 & 30 & 0.5 & 0.00021 & 0.1024 \\
\hline
\end{tabular}

oversized valves were considerably larger than those sized using the ISA standard. This leads to the situation where the valve is almost closed during normal conditions, and the valve is operating in the non-linear area. The effect of valve size on the quality of control was minor. Overshooting due to flow disturbances was compensated slightly better when the valves were sized according to the ISA standard. In contrast, changing the set points of the pulp level with oversized valves often even resulted in better performance indices.

The geometry of the cell had the greatest effect on the performance of the level control. A difference in performance was clearly evident when the same config- urations with ideal cells and with different geometry cells were compared. In every case the results were clearly better.

Feed-forward control implemented with PI control improved the compensation of the disturbances in every case. An adaptive feed-forward control gain could result in even bigger improvements in control performance.

\section{Further studies}

The simulation platform introduced in this paper has been used in further studies to develop and compare 


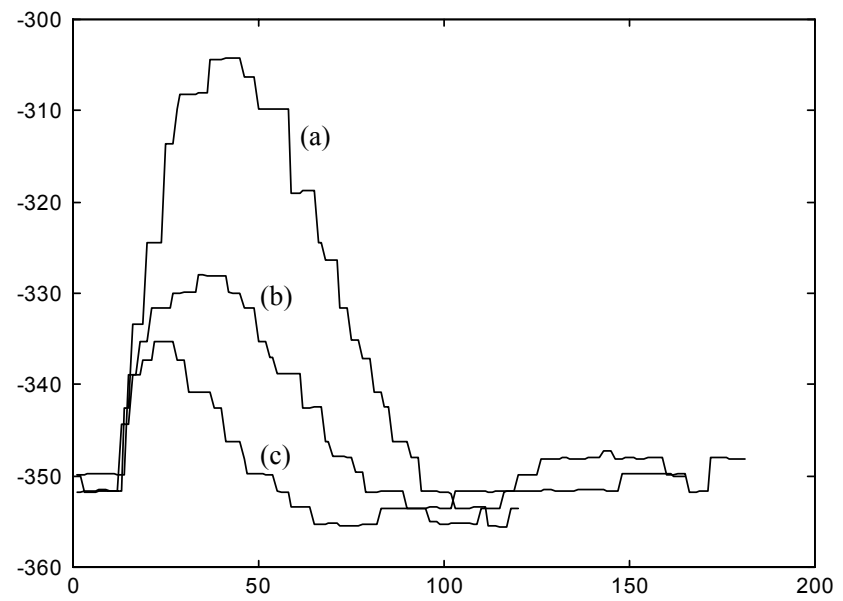

Fig. 13. Responses of the level to a change in pulp feed $\left(0.35 \rightarrow 1.1 \mathrm{~m}^{3} /\right.$ $\mathrm{min}$ ). The biggest overshoot (a) is obtained using a PI controller, and noticeable improvements in control performance are achieved by implementing additional feed-forward controllers (b and c).

advanced multivariable control strategies for flotation cells. Control performance of feed-forward control, decoupling and different multivariable control methods have been studied, discussed and published by Kämpjärvi and Jämsä-Jounela (2002).

\section{Acknowledgements}

The authors would like to thank Outokumpu Mintec. In particular, special thanks to Heikki Laurila who helped with the practical details. Financial support of TEKES is also gratefully acknowledged.

\section{References}

Andersen, R., Gronli, B., Olsen, T., Kaggerud, I., Ramslo, K., \& Sandvik, K. (1979). An optimal control system of the Rougher Flotation at the Folldal Verk Concentrator, Norway. Proceedings of the 13th international mineral processing congress, Vol. II (pp. 1517-1540). New York, USA.

Hammoude, A., \& Smith, H. (1981). Experiments with self-tuning control of flotation. Proceedings of the 3rd IFAC symposium on automation in mining, mineral and metal processing (pp. 213-218). Oxford, UK.

Jämsä, S.-L., \& Herbst, J. A. (1988). A simulation study of expert control system for flotation. Software for Computer Control 1988 (pp. 67-75). New York, USA.

Jämsä-Jounela, S.-L., Laurila, H., Karesvuori, J., \& Timperi, J. (2001). Evaluation of the future automation trends in control and fault diagnostics - a case study in flotation plant. Proceedings of the 10th IFAC symposium on automation in mining, mineral and metal processing. Tokyo, Japan.

Kämpjärvi, P., \& Jämsä-Jounela, S.-L. (2002). Level control strategies for flotation cells. Proceedings of the 15th IFAC world congress on automatic control. Barcelona, Spain.

Koivo, H., \& Cojocariu (1977). An optimal control for a flotation circuit. Automatica 13, 37-45.

Niemi, A., Maijanen, J., \& Nihtilä, M. (1974). Singular optimal feed forward control of flotation. IFACIIFORS symposium on optimization methods-applied aspects (pp. 277-283). Varna, Bulgaria.

Schubert, J. H., Henning, R. G. D., Hulbert, D., \& Craig, I. K. (1995). Flotation control - a multivariable stabilizer. XIXth IMPC, Vol. 3 (pp. 237-241). San Francisco, USA.

Stenlund, B., \& Medvedev, A. (2000). Level control of cascade coupled flotation tanks. Future trends in automation in mineral and metal processing, IFAC workshop 2000 (pp. 194-199). Helsinki, Finland.

Zargiza, R., \& Herbst, J. A. (1987). A model based feed forward control scheme for flotation plants. 116th AIME annual meeting (pp. 23-27). Denver, CO, USA. 